\title{
Minister of Railways P.P. Melnikov (1804-1880) and His Contribution to the Development of the Russian Applied Mechanics School
}

\author{
Alexander V. Soldatov ${ }^{a}$ \\ and Margarita M. Voronina ${ }^{\mathrm{b} *}$ \\ ${ }^{a}$ Herzen State Pedagogical University of Russia \\ 48 Moika river Str., St. Petersburg, 191186, Russia \\ ${ }^{b}$ State University of Means of Communications \\ 9 Moskovsky, St. Petersburg, 190031, Russia
}

Received 19.02.2018, received in revised form 21.05.2018, accepted 29.05.2018

Applied mechanics as such appeared in Russia in the 1820-s in Higher Technical School, namely at the Institute of the Engineers Railways Corps P.P. Melnikov, an outstanding statesman, professor, an honorary member of St. Petersburg Academy of Science, the Minister of Railways, the author of the project and the builder of the first railway in Russia: St. Petersburg-Moscow, the founder of the first perspective general railway in Russia, played an important role in all these developments.

Keywords: Institute of the Engineers Railways Corps, applied mechanics, railways, Minister of Railways, St. Petersburg Academy of Science, Russian railways, Petersburg-Warsaw line.

DOI: 10.17516/1997-1370-0287.

Research area: history.

P.P. Melnikov was born on July 22, 1804. $\mathrm{He}$ is known to be born in Moscow. ${ }^{1} \mathrm{He}$ was educated well enough to continue his studies in St. Petersburg. In those years, choosing an educational institution was not enough. Founded in 1809, the Institute of the Corps of Railway Engineers was probably the best. It was opened for training engineers of various types and became the first Russian higher technical educational institution for transport and construction. The education procedure was adopted from Parisian Polytechnic school; some of its graduates, such as A.A. Fabre, K.I. Potier, P. Bazaine and
J. Destrem and later - G. Lame, B. Clapeyron were invited to the Railway Corps of Engineers for teaching and construction works. In 1815 P. Basen began to deliver lectures in further mathematics, K. Potye - in descriptive geometry, and J. Destrem - in mechanics.

The famous Spanish scientist, mechanic and builder A. Betancourt was the head of the Institute from the day of its foundation until $1824^{2}$. In 1820, he initiated establishment of the Military Building Railways School, attached to the Institute for training technicians and builders. Professors and teachers of this Institute taught

(C) Siberian Federal University. All rights reserved

* Corresponding author E-mail address: soldatov2012@yandex.ru; voronina.pgups@gmail.com 
there. In 1821, P.P. Melnikov was admitted to this school and finished it with honours. A. Betancourt noticed Melnikov and offered him to continue his study at the Institute. ${ }^{3}$ He was admitted at once to the third-year course of the Institute.

At the Institute, applied mechanics was the most important subject in engineering education; in 1823, it was separated from theoretical mechanics as an independent discipline. In those times, the course in applied mechanics contained steam machinery studies, road building and mechanisms, as well as other disciplines connected with other mechanical devices, transport structures and water supply. The invited professor B. Klapeiron gave lectures in applied mechanics. P. Melnikov listened to his lectures. In 1825, he graduated from the Institute of the Corps of Railway Engineers with good progress in science, and his name was placed on the marble board of honour. "Brilliant mind, quickness and Melnikov's talent, wrote railway engineer V.A. Panaev wrote, were noticed back when he studied at the Institute of the Corps of Railway Engineers"'. There is no coincidence, that the corresponding member of St. Petersburg Academy of Sciences P. Bazine, appointed to be the Director of the Institute in 1824, mentioned in his report in 1825: "P.P. Melnikov was the first among the graduates, an officer, different from them both in behaviour and in his talent ${ }^{5}$ ".

That is why the young railway engineer was allowed to stay at the Institute as a tutor in applied mechanics, taught by B. Clapeyron up to 1830 . After B. Clapeyron left, P.P. Melnikov continued the lectures, considerably expanding the curriculum $^{6}$, which is proven by the comparison of the examination questions of the years 1830 and 1833. Besides, P.P. Melnikov was the first to deliver lectures in Russian language (until 1830, it was common to teach in French). In 1830, his lectures were lithographed. Unfortunately, they were lost. In those years, P.P. Melnikov was engaged in design and development of water raising mechanisms with the use of a steam machine in the London channel, in clearing the Volkhov River rapids, in improvement of navigation on the West Dvina. In autumn 1831, P.P. Melnikov became an assistant professor, in November 1833 - a professor in applied mechanics. At the same time, he was elected as a member of the Construction and Hydraulics Committee, which inspected all construction sites of St. Petersburg. He was supervised the construction and erection of the new wooden dome of Troitsky Cathedral in St. Petersburg, built by the architect V.P. Stasov to replace the old one, blown off by the wind. The dome was erected without any external scaffolding, all its parts were made downstairs and then lifted up a slopping plank structure built inside the cathedral. Its width was $24.8 \mathrm{~m}$, and the height was $25.6 \mathrm{~m}$. This way of construction, developed by P.P. Melnikov and by his assistant, a railway engineer I.F. Buttatsem, was a great contribution to the theory and practice of the art of construction. The new dome of the cathedral was the second in size among the wooden domes in Europe.

P.P. Melnikov was interested in all branches of engineering art, especially in British railway construction. In 1835, he was the first in Russia to published a book titled "About railways", intended to inform Russian engineers of the arrangement of railways, the variety of main technical parameters, motors, rolling stock and so on. The book was of great importance for engineers was widely recognized. First of all, this book demonstrated the opportunity of building steam thrust railways in Russia and explained its economic feasibility. The author underlined that the speed of movement the people had never experienced before would doubtlessly influence the economy, trade and defence of the country. Besides, "About railways" was a teaching aid used in the applied mechanics course at the 
Institute. The number of copies printed was extremely large for an academic book in those times, reaching 600 copies. The book was especially valuable, for it promoted a new means of transport, being written in the time when the discussion of the possibility to build railway in Russia was at its peak.

In 1836 P.P. Melnikov published a new part of the course in applied mechanics, titled Basics of Practical Hydraulics ${ }^{8}$. It was published as s practical guide in hydraulics for engineers. The Council of the Institute remarked, that the work was "the best of all collected works written in applied mechanics in the modern time". Melnikov P.P. was awarded for the book; moreover, his merit was said to belong not only to the Institute, but to the whole country.

In 1838, P.P. Melnikov published the lithograph of his lectures in applied mechanics ${ }^{10}$. The thesis consisted of 460 pages. It presented the basic description of motors, transmitting and operating mechanisms. The course consisted of three parts: the first part was a research of different motor types, with an emphasis on steamgeneration, steam machines and mechanisms; the second part was devoted to the ways of transmission and transformation of movement. The author paid great attention to the theory of flywheels and movement transmission by means of toothed gearing. Water-lifting, freight carrying, dredging machines and other machines, used in railways are described in the third part of the course. The course by Melnikov was the first teaching aid in applied mechanics written in Russian language for a higher technical school. The book was made for students with good theoretical background, especially in analytical mechanics, descriptive geometry and in further mathematics.

In 1837 P.P. Melnikov was sent on a long mission to European countries as one of the best engineers of the Railway Corps. A Polish specialist, Stanislaw Kierbedz (1810-1899), his student and later his colleague and a railway engineer, was chosen to accompany Melnikov in his trip as an assistant ${ }^{11}$. S. Kierbedz was born in a noble Polish family in Kovensky province, in 1828 he graduated from Vilna University with the scientific degree of a candidate of physical and mathematical sciences and later, in 1831, from the Institute of Railways. The graduates of that time passed examinations in 18 subjects, graded on a scale from one to ten. The highest possible score was 180 marks. S.V. Kierbedz got 174.68, being the second among all the engineering graduates. After Institute, S.V. Kierbedz got engaged in teaching, research and engineering. He was in close personal contact with P.P. Melnikov and joined him on a long mission lasting from 1838 to 1839 . For 15 months, they inspected railways, steam machinery plants, building mechanisms, large engineering constructions; listened to lectures about building and applied mechanics in England, France, Germany, Belgium and Austria. Upon arrival, P.P. Melnikov and S. Kierbedz made a report in 5 volumes, consisting of 1673 pages and 190 sheets of drawings $^{12}$. This report was a fundamental work connected with many engineering problems including applied mechanics. It was the first book to present a lot of solutions in construction of certain railways and the railway system as a whole.

Later, for over 10 years, S.V. Kierbedz taught applied mechanics at the Institute of Railways as a professor. In 1842 he was appointed as a director of works in the erection of the first permanent bridge across the Neva in St. Petersburg; he became the builder of the first steel railway in Russia. In 1860, S.V. Kierbedz was appointed as a chief in the $7^{\text {th }}$ railway district of Warsaw. In 1857-1864, the engineer designed and built the Kierbedź Bridge, the first permanent bridge across the Vistula river. 
After returning from abroad, P.P. Melnikov continued lecturing in applied mechanics at the Institute until the year 1842. Besides, he had been giving lectures at St. Petersburg Mining Institute since 1834 and at the Artillery College from 1833 to 1939. Upon the initiative of P.P. Melnikov, this course was taught at St. Petersburg Technological Institute and at the Institute of Civil Engineers, where it was presented by his former student N.F. Yastrezhemsky. S.V. Kierbedz taught the course in applied mechanics "from his own notes" at the General Engineering college, where famous scientists G.E. Pauker and N.P. Petrov used to study. S. Kierbedz also gave lectures in applied mechanics the "real department" of St. Petersburg university, established for training administrative workers and teachers of engineering sciences in 1839. The ideas on the application of the analytical mechanics methods to the traction theory, expressed by Melnikov, were developed by A.G. Dobronravov, a railway engineer. Therefore, P.P. Melnikov succeeded in developing a common course in applied mechanics and spreading it around educational institutions of the country. By the end of 1830$\mathrm{s}$, intensive railway development had begun in England and America. It is worth mentioning that in this regard, Russia and the North America had much in common, such as the landscape, the distances, abundance of building timber, rare locality. It explains the great interest for railways in America. In 1839, P.P. Melnikov and N.O. Kraft as railway engineers were sent to the North America to see its railway industry. They stayed there until 1940. This trip developed contacts between Russian and American transport experts.

N.O. Kraft (1798-1857) graduated from the Institute of Railway Engineers in 1820, managed construction works in many regions of the country, took an active part in the development of the railway project St. Petersburg - Moscow.
In 1842 , he was appointed as a chief of the south board, responsible for the building of St. Petersburg-Moscow railway. In 1855, N.O. Kraft was appointed as a chief of Warsaw railway district and died in Warsaw. He was awarded with the Order of Saint Stanislaus and the First Class Order of Saint Anna.

The researchers had been on the mission for two years and presented a report upon their arrival. The first four parts of the report were devoted to the description of American railways and theoretical research on design and building problems. The fifth part of the report was devoted to the basics of building St. Petersburg - Moscow railway. P.P. Melnikov published a number of articles in the Railway Journal on railway building, applied mechanics and construction mechanics, considerably expanding the corresponding academic courses. P.P. Melnikov's works are the basis of Russian domestic transport mechanics.

In the following years, P.P. Melnikov monitored the building of St. Petersburg Moscow railway. The research began in February, 1842, the building of railway started in summer 1843. P.P. Melnikov was appointed as a chief of the North Board (Petersburg Bologoe), and N.O. Kraft was appointed to the South Board (Bologoe - Moscow). The building of St. Petersburg - Moscow railway (1842-1851) established the foundation of Russian transport science. In that time, there was no theory for bridge building or hydrotechnical construction. There was no railway mechanics and other branches of science. All problems were solved in the process. The most important theoretical and practical solutions were found by P.P. Melnikov.

P.P. Melnikov paid great attention to the designing of the permanent bridges across rivers, especially across the Volkhov, the Volga, the Msta etc. D.I. Zhuravsky, a railway engineer, developed a new theory for lattice girder bridge design, which served as the basis for the construction 
of all the largest bridges on St. Petersburg Moscow railway; P.P. Melnikov helped and guided him in his work. Construction of this railway branch played an important role in further development of railway transport both in Russia and abroad. The foundations of Russian railway building were focused on this main line. After completion of St. Petersburg - Moscow railway construction, P.P. Melnikov wrote a number of works on railway transport, especially in the field of railway classification. His researches of Moscow - Black Sea and other lines are the basis for all Russian railways, developed predominantly under his auspices in the following years. In 1858, P.P. Melnikov and S.V. Kierbedz were recognized as honoured members of St. Petersburg Academy of Sciences. They were the first engineer academicians in Russia.

In 1857, a number of entrepreneurs were united into the Main Russian Railway Society. The Society won the right to build St. Petersburg Warsaw line and a number of other new railways. Thus, the Department of Railways was dismissed from new railway building, though retained the right to technical control. In January 1858, P.P. Melnikov was appointed as a chief inspector of private railways and as a member of the Council of the Chief Administration of Railway and Public Buildings. He worked to control the quality of the research and different stages of construction. However, the contractors often modified the projects or could leave them incomplete. For this reason, in 1858 P.P. Melnikov resigned from the position of the Chief Inspector, protesting against private railway construction: he confirmed, that railway transport must belong to the state.

In 1862, P.P. Melnikov was appointed as an Acting Administrator, and then, as the Main Administrator of Railways and Public Buildings. In 1865, due to the establishment of the Ministry, P.P. Melnikov became the Minister of Railways of the Russian Empire. Within the Ministry, the
Scientific Committee was founded to control all innovations in transport science. P.P. Melnikov was engaged in the academic training at the Institute of Railways. Particularly, thanks to his efforts, 15 students previously expelled for their political views, were allowed to resume their studies. He believed those talented people to be useful for the country and claimed, that only specialists should be allowed to teach at the Institute of Railways.

As a minister, P.P. Melnikov implemented the policy of entrusting the construction of railways and other transport facilities to the state. Moreover, he considered it necessary to develop the domestic metallurgical and coal mining industries in the country to build "plants capable of producing locomotives, tenders, carriages and other mechanical equipment of Russian metals by Russian workers ${ }^{13}$ ". To achieve it, P.P. Melnikov had to start an unequal opposition with Grand Duke Michael, the brother of Nicholas I. Nevertheless, Pavel Petrovich struggled to defend the interests of the state. For example, he protested against granting the right of building the Donetsk railway to a Western entrepreneur John Hughes on his own discretion. The Minister confirmed that all railways engaged in the coal mining process had to be built in compliance with the terms of reference of the Railway Department.

In 1867, it was suggested to sell Nikolaevsk (St. Petersburg - Moscow) railway to the Main Russian Railway Society. P.P. Melnikov flatly refused, explaining that this act "would be admitted as a symptom of extreme financial insolvency ${ }^{14}$ ". However, in 1868 the railway was sold. Interestingly, in his memories (1870) P.P. Melnikov wrote that the railway would be returned to the state in 30 years ${ }^{15}$. At the end, he turned out to be right. In 1894, the railway was purchased by the Treasury. In April 1869, P.P. Melnikov was dismissed from the post of Railways Minister "for health reasons", but 
actually, because of his disagreements with the railway policy. However, he remained a Member of the State Council.

Since 1872 , he had been a member of the Department of State Policy. During the late years of his life, he lived by Luban station, in the suburbs of St. Petersburg. Though he did not participate in railway building, he still served as a consultant in many construction projects for buildings and bridges.

\footnotetext{
Voronina, M.I., Voronina, M.M. (1980). Pavel Petrovich Melnikov. Leningrad, "Science”.

2 Bogoliubov, A.N., Pavlov, V.E., Filatov, N.F. (2002). Agustin Betancourt (1758-1824). Scientist, engineer, architect, townplanner. Nizhni Novgorod.

Delvig, A.I. (1912). My recollections. Volume 1, Moscow, p. 63.

Panaev, V.A. (1889). The four ministers of railways. 1833-1869. St. Petersburg, p. 40.

St. Petersburg Central State Historical archives (1825). F. 381, op. 13, d., 76, 1. 9.

Materials of the Institute conference for 1836-1839. Manuscript. Library PSUR, 1.

Melnikov, P.P. (1835). About railways. St. Petersburg.

8 Melnikov, P.P. (1836). Foundations of practical hydraulics or about movement of water in different cases and its effect under strike and resistance, St. Petersburg.

9 Proceedings of the Institute Conference for 1836-1839. Manuscript. Library of Petersburg State University of railways (PSUR), 14 (numeration of pages is absent).

10 Melnikov, P.P. (1838). Notes in practical mechanics. Lithographic edition. St. Petersburg.

11 Voronin, M.I., Voronina, M.M. (1982). Stanislav Valerianovich Kierbedz, 1819-1899. Leningrad, "Science".

12 Melnikov, P.P. Report about trip to Europe in 1837, 1838. Manuscript. Library PGUPS.

13 Russian State historical archive (1866). F. 219. Op. 1. D. 7396. L. 23.

14 Russian State Historical archive (1867). F. 446. Op. 26. D. 14. L. 17.

15 Recollections of P.P. Melnikov published by M.I. Voronin and others "P.P. Melnikov - engineer, scientist, statesman" (2003). St. Petersburg, p. 223-400.
}

\title{
Министр путей сообщения П.П. Мельников (1804-1880) и его вклад в развитие русской школы прикладной механики
}

\author{
А.В. Солдатов ${ }^{\mathrm{a}}$, М.М. Воронина \\ а Российский государственный педагогический \\ университет им. А.И. Герцена \\ Россия, 191186, Санкт-Петербург, наб. реки Мойки, 48 \\ ${ }^{\sigma}$ Петербургский государственный университет \\ путей сообщения Императора Александра I \\ Россия, 190031, Санкт-Петербург, пр. Московский, 9
}

Прикладная механика как самостоятельная наука оформилась в России в 20-х годах ХІХ века в высшей технической школе, а именно в Институте Корпуса инженеров путей сообщения. Важную роль в развитии и распространении этого направления сыграл Павел Петрович Мельников, выдающиийся государственный деятель, профессор, почетный член Петербургской Академии наук, министр путей сообщения, автор проекта и строитель первой железнодорожной магистрали в России: Санкт-Петербург - Москва, создатель первой перспективной генеральной сети железных дорог России.

Ключевые слова: Институт инженеров железнодорожного корпуса, прикладная механика, РЖД, министр путей сообщения, Санкт-Петербургская Академия наук, Петербурго-Варшавская линия.

Научная специальность: 07.00.00 - история. 